\title{
The Implementation Of Fast, Safe, Modern, Accountable and Transparent Sub District Administration Service Applications As An Innovation Of Public Services In Tanjungpinang Barat, Indonesia
}

\author{
Nur.A.Dwi Putri \\ Raja Ali Haji Maritime University \\ Tanjungpinang, Indonesia \\ Email: na_dwiputri@yahoo.com
}

\begin{abstract}
In Order to improve the quality of service for the community, the sub district government of Tanjungpinang Barat innovate by launching the application of sub-district administration service that is fast, safe, modern, accountable and transparent or abbreviated with "PAK CAMAT". This Android-based applications will facilitate the public to get administrative services and channeling aspirations. But until recently, the app that was unveiled on December $16^{\text {th }} 2016$ is not working properly. This is due to several factors such as leadership changes, budget constraints, infrastructure that has not been fully supported and the rejection and lack of public awards for the innovation caused by the inability of the community to operate it.
\end{abstract}

Keywords-Implementation, public services

\section{INTRODUCTION}

Application-based service system launched by Tanjungpinang barat sub district is a form of service made to answer the public's insecurity of administrative services that are not effective and efficient. Administrative services, especially in relation to moving in and out, take more than one day to complete because they have to go through a long bureaucratic level from the RT / RW until to The Department of Population and Civil Registration. Therefore, the sub district government hopes that with this application, the formerly sluggish service can be transformed into fast, secure, modern, accountable and transparent.

In addition to administrative affairs in the application is also available reporting services for the people who want to report to the district government if there is damage to facilities and infrastructure in the district or want to report dissatisfaction with the services provided by the district government. This is a new breakthrough considering that until now damaged facilities and infrastructure are left without adequate supervision from sub-districts or from communities domiciled in those districts.

With the innovation of services undertaken by the sub district government expected the community as a customer can feel satisfaction. However, unfortunately the application launched on December $16^{\text {th }} 2016$ is not running well. Until now, only one hundred people have downloaded this application, the people who manage the administration or who want to report do not use this application, they prefer to come directly to the district office, where everything is done conventionally. On the basis of the above phenomenon the authors are interested to find how the application of this service application and the factors that influence it. So the results of this study can be beneficial for the government to improve innovation and society get satisfaction with the services provided.

\section{METHODS}

The method used in this research is descriptive qualitative. In this study researchers will describe the implementation of fast, safe, modern, accountable and transparent applications based on primary and secondary data obtained at the time of interview with informants who know the problems. Furthermore, researchers used triangulation method by matching the answers of each informant to get the truth and conclude the problems that occur. 


\section{DISCUSION}

\section{A. Innovation and E-Government}

Innovation is one form of bureaucracy reform. Bureaucratic pathology that have always been the cause of the slow process of administration slowly began to change with the reform of the bureaucracy, especially in terms of public services. The government began to innovate in order to create a clean, effective and efficient government. The understanding of Innovation itself is a process whereby some individuals or groups identify the most crucial problem then develop solutions to the problem. Not only solutive but also can make a significant contribution to the improvement of effectiveness, efficiency, and quality of public services (Howie in Holidin 2016: 35).

Efficiency in relation to the provision of public services is one of the important aspects, according to Thamrin (2013: 90) there are some things that need to get serious attention from the local government in carrying out public service functions to the community, among others: a) service requirements are limited to conditions that are directly related to the achievement of service targets while maintaining the integrity between the requirements and the outputs, b) should be prevented from repeating the fulfillment of the requirements, in the case of the community service process concerned is required the completeness of the requirements of other work units/government agencies (c) the output of services received by the public does not require costs beyond the applicable provisions, d) the condition and ability of the community to pay, and e) based on applicable laws and regulations. While effective it self relates to the timeliness in the implementation such as the existence of operational standards and procedures for each service provided.

In today's modern times, the alternative to creating effective and efficient services is with the help of technology. The government can apply the concept of electronic-based government in improving services. Understanding of egovernment by the World Bank in Indrajit (2004: 2) is related to the use of information technology (such as: wide area networks, internet and mobile communications) by government agencies that have the ability to change government relationships with their citizens, businesspeople, and other government agencies. This technology can have various objectives, such as: better delivery of government services to its citizens, increased interaction with business and industry, community empowerment through information access, or more efficient government management. Expected results may include reductions in corruption, increased transparency, increased convenience, increased revenues and/or cost reductions.

According to Indrajit (2004: 5) the benefits of implementing the concept of e-government for a State, among others:

1. Improving the quality of government services to its stakeholders (community, business and industry), especially in terms of effectiveness and efficiency in various areas of state life;

2. Improving transparency, control, and accountability of governmental administration in order to implement the concept of Good Corporate Governance;

3. Significantly reduce total administrative costs, relationships, and interactions issued by the government and its stakeholders for the purposes of daily activities;

4. Provide an opportunity for the government to gain new sources of revenue through its interaction with interested parties; and

5. Creating a new community environment that can quickly and accurately answer the various problems faced in line with the various global changes and trends that exist; and

6. Empower communities and other parties as government partners in the process of making public policies equally and democratically.

With the various benefits provided by e-government is certainly very helpful for the government, but for developing countries such as the implementation of e-government Indonesia itself is still running slow. There are several elements of successful e-government project management according to Indrajit (2004: 62-68), among others:

a. Political environment

What is meant by this element is the state or political atmosphere in which the project is located or implemented. Based on the results of the study, there are two types of projects related to this. The first "Top Down Project" (TDP) in which the existence of a project is determined by the initiative of the executive environment (eg the president or prime minister) as the supreme authority of the government, or sponsored by the legislature as a mandate. The second is the "Bottom up Projects" (BUP) implemented because of the idea or initiative of the head unit or employee (bureaucrats) residing in one of the government agencies or departments.

b. Leadership

The scope of leadership to manage there are three things, namely:

1. The various political pressures that occur on egovernment projects that take place both from optimists and pessimists;

2. The various resources required and allocated by the relevant e-government project, such as human resources, finance, information, equipment, facilities and so on;

3. A number of interests from various groups on the existence of e-government projects that run.

c. Planning

Planning is a very important stage, because it is at this early stage that a thorough and detailed picture of the planned existence of an e-government initiative is projected. 


\section{d. Stakeholders}

Stakeholders here are the various parties who feel they have an interest (directly or indirectly) towards the project of the implementation of the related e-government project.

e. Transparency/visibility

Transparency in e-government projects is closely related to the existence of stakeholders, in the sense that the word is that all data and information about the details of the project and the ongoing status of the project must be freely accessible to such diverse stakeholders.

\section{f. Budgets}

It is no longer a secret that the power of financial resources budgeted on an e-government project is one of the strategic elements and determines whether or not a project is worthwhile.

g. Technology

It is a fact that the choice of technology to be implemented in an e-government project is highly dependent on the available budget.

h. Innovation

It relates to the ability to create ideas and implement ideas in implementing e-government primarily because of the large number of stakeholders involved and the high complexity of related projects.

In addition to the eight elements of success above there is also a basic problem in the application of e-government as occurs in service applications in Tanjungpinang Barat, as according to Aziz (2008) in public service seminars and egovernment, there are three main issues of e-government applications, among others related to cultural issues, leadership and infrastructure:

- Cultural issues that are resistance and rejection of e-gov, lack of awareness and respect for e-gov, and do not want to share data and information.

- Issues related to leadership are conflict between central and regional, regulation, budget allocation and standardization.

- As well as infrastructure-related issues such as digital inequality, inadequate infrastructure and lack of system services

B. The implementation of fast, safe, modern, accountable and transparent sub district administration service applications

Fast, safe, modern, accountable and transparent sub district administration service applications or abbreviated 'PAKCAMAT' is one form of public service innovation available in Tanjungpinang Barat. This application consists of three types of services that are moving in, moving out and reporting services. The app that was unveiled in December 2016 is still running today but no users have used it. The community prefers to come directly to the sub district office to complete its affairs, thus making the application that aims to facilitate this society is not going well. There are several factors that cause the service application has not been running properly, among others:

\section{Cultural Factors}

After inaugurated in December 2016 last year, this application can be officially used by the community, especially the people residing in Tanjungpinang Barat. Tanjungpinang barat consists of four villages such as bukit cermin, kamboja, kampong baru, and Tanjungpinang Barat with a total population of 61,431 people. Until September 2017 , no user has been using the application. The subdistricts have socialized the application at the time of inauguration and once after the invitation by inviting RT and RW. Subsequently the Tanjungpinang Barat government also continue to socialize the application to the existing village in the district of Tanjungpinang Barat by directly communicating.

However, although the socialization has been done it turns out that the application has not been utilized, according to the RT and RW they have delivered what is socialized in the sub district to the community but only in the community who want to take care of the letter either moving letter coming or going. RT and RW are the main gateways to socialize this application because if people want to take care of moving letter come and move out then the plot starts from requesting letter of introduction from RT and RW. However, the response from the community after the RT and RW submitted is that they are reluctant to use the application for various reasons one of them is that they do not have enough time to download the application and follow the instructions therein.

They prefer to request assistance from the RT or RW to take care of it. In addition there are also other problems that the RT and RW also not all have the ability to use the application due to their advanced age, data from Tanjungpinang Barat shows that the age of the RT and RW average is over 60 years. With the rejection and the absence of the award then the application cannot run maximal because people prefer the conventional way.

\section{Leadership}

At the time this application was launched was at the time of leadership Bobby Wira Satria, but after more than 3 months of the application is official to use, there is a change of leadership, with the change of leadership ultimately affect the implementation of this application. Because in running a change requires a good commitment from the leader. In addition, the budget factor is also the cause of this application is not running, with cut budget at the regional level automatically affect the funding for the provision of facilities and infrastructure supporting this application. The impact of the budget cuts is where the Tanjungpinang Barat government cannot meet the facilities and infrastructure at the village level, making it difficult to integrate data and information through the application. For this reason the villages finally chose to keep using conventional methods rather than in the network. 


\section{Infrastructure}

In running this application requires facilities and infrastructure, among others in the form of computer/ tab/smartphone, wifi, and electricity. However, there are constraints on power supplies, insufficient power supply can make frequent shutting down so that greatly affects the running of this application. If the government has to provide generators then it is hampered from the budget side.

\section{IV.CONCLUSIONS}

The conclusions of this study are:

Innovation of public service in the form of fast, safe, modern, accountable and transparent sub district administration service applications in Tanjungpinang Barat not yet running well, this is caused by several factors such as leadership turnover, limited budget, unsupported infrastructure and rejection and lack of appreciation from society which resulted from the inability of the community to operate the application. As for suggestions that can be given is there is no alternative or choice for the community to take care of the letter, the district government must choose between using the application or conventional, if the government chooses to use the application then the community will be forced to download and follow the existing procedures. In addition, there needs to be coordination between related institutions either with subdistrict, villages and Department of Population and Civil Registration for this application to be integrated. And the last suggestion is that the government should continue to socialize step by step until the community can use it well.

\section{REFERENCE}

[1] Indrajit, Richardus Eko. Electronic Government. Andi Yogyakarta. Yogyakarta, 2004

[2] Holidin defny, dkk, Bureaucracy reform in transition. Prenadamedia Group. Jakarta, 2016.

[3] Thamrin, Husni, Law of public services in Indonesia. Aswaja Presindo. Yogyakarta, 2013.

[4] Azis, Herry Abdul, "the integration of e-government: challenges, policies and implementation". Jakarta: public services and egovernment conference, Bappenas, on Dec $19^{\text {th }} 2008$. 